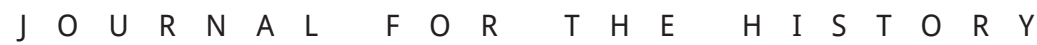

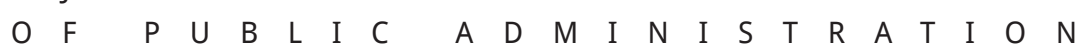

$\begin{array}{llllllllllll} & O & L & \mathrm{U} & \mathrm{M} & \mathrm{E} & 1 & 2 & 0 & 1 & 6\end{array}$

$\begin{array}{llllllllllll}P & A & G & E & 1 & 2 & 4 & - & 1 & 3 & 7\end{array}$

D O I : $10.2478 /$ ADHI-2018-0007

\title{
Administrative History and the Theory of Fields: Towards a Social and Political History of Public Administration
}

\section{CAROLINE DUFOUR*}

\author{
"History is a powerful means for breaking with the obviousness of the \\ established order." PIERRE BOURDIEU, INTERVIEW WITH L. J. D. WACQUANT ${ }^{1}$
}

When public administration is studied from a historical perspective, the inquiry often focuses on the analyses of its formal structures, its functions, and the characteristics of its employees. Focusing on these dimensions, classics as well as recent works have developed a body of knowledge focusing on the notions of persistence and change, while at the same time describing the specificities of particular cases. ${ }^{2}$ Yet, maybe because of the disconnection that existed for a long time between history and the social sciences ${ }^{3}$ - the first being stereotypically associated with the past and idiographic research, the second with the present and a nomothetic approach - this academic tradition has prevented many researchers from unravelling the social and political history of the organizations and practices associated with the administration of the state. In particular, how conflicts and power relationships about administrative stakes shape the development of public administration has yet to be studied.

Works in the tradition of French sociologist Pierre Bourdieu's theory of fields suggest that political sociology can help explore this territory and open up the specialty to new ways of thinking. The theory of fields moves away from the institutional conception of the state, setting aside the idea of a monolithic bloc or ho- mogeneous actor. Instead, both the state and public administration are considered to be fields of relationships, in which agents with antagonistic interests defend their positions, positions that are the product of historical conflicts. These conflicts then give way to administrative practices. Since 2007, a few European scholars have used this approach to reveal the social and political nature of contemporary public administration, ${ }^{4}$ but the potential of the theory of fields for the study of administrative history remains uncharted, especially in North America, where Bourdieu's works are little known and used in the study of public administration.

This article explores how the theory of fields, by encouraging a critical analysis of what the state does and produces, starting from its practical effects and its dynamics, ${ }^{5}$ can bring a new perspective to studying the history of public administration. To do so, it first describes the theory and summarizes its conceptualization of the state and public administration. Next, it explains how the theory of fields can bring scholars who are interested in administrative history to question the intellectual categories they use as well as their research practices. It uses one case, taken from a research project on the history of the Canadian federal administration, to illustrate 
how changing these categories and practices can lead to a new reading of administrative history. Overall, the article looks at the body of theoretical and empirical work that has developed around the theory of fields, from the perspective of scholars open to new and fruitful ways of researching administrative history.

\section{The theory of fields: its perspective on the state and public administration}

To be able to see in what ways the theory of fields can be useful to studying the history of public administration, it is necessary to look both at the theory itself and at the way that Bourdieu and scholars who have followed his intellectual leadership have explained the nature and role of the state and public administration. ${ }^{6}$

\subsection{Linking practices to their genesis}

The core concepts of the theory of fields - capital, field, and habitus - are "inherently historical « in three ways. ${ }^{7}$ First, they relate to a reality taking place at a specific time and place. Second, they represent "a form of incorporated history «. And third, they produce an understanding of reality "that is open to conjuncture, contingency, and radical discontinuity“. Overall, the theory provides a framework that allows understanding social reality by linking structures, agents, and institutions in a temporal perspective.

Capital is defined as a resource that agents - individuals and organizations - have, can accumulate over time, and use to interact among each other. There are four types of capital: economic, cultural, social, and symbolic, and a specific form of it exists only under specific social, political, and economic conditions. ${ }^{8}$ The volume of capital that an agent has at its disposal determines its position in a society composed of various fields - that is, structures or networks of relationships among positions. ${ }^{9}$ The emergence of a field is a historical product as it is made possible through a group of founding agents under, again, specific circumstances, and it reflects the differentiation of a social activity over time. Once a field is established, it shapes and channels "the manner in which sexternal ing them appear a part of the ongoing history and operation of the field itself « ${ }^{10}$ Possessing certain forms of capital allows agents to believe in the value of each activity in a field. This is what Bourdieu calls the sillusion «: "the fundamental beliefs in the interest of the game and the value of the stakes «; ${ }^{11}$ it allows agents to participate in a field's activities and conflicts. A stake is the accumulation of one form or another of capital and, ultimately, leads to the domination of a field over a more or less long period of time. Yet its activities, changing external circumstances, and the arrival of new agents can all change the principles that establish the domination of one group of agents over the field and alter the definition of what is valuable. Thus, the dynamic of a field is constantly changing, allowing for change - and history - to take place.

Even though each field has its own capital structure and logic, its autonomy - that is, the power it has to define its own norms and criteria of functioning ${ }^{12}$ - can be limited in two ways. ${ }^{13}$ First, because fields are linked with one another, they present a structural homology: agents in more than one field tend to keep similar positions by converting their capital. ${ }^{14}$ Second, the similarity in the structures of fields is linked to the domination of certain fields over others; this is particularly true of the field of power, which has the power to impose its structure over others. A field's autonomy also raises the question of its limits. Even though they can be difficult to identify, the limits of a field correspond to that point of the social space where the influence of a field is not felt at any specific time. Thus, a field's borders are constantly changing, depending on the stakes and the specific socio-economic context, and they can be identified only through empirical research.

In the theory of fields, the concept of habitus links agents to fields. The habitus is a "system of durable and transposable dispositions, structured structures that are predisposed to function as structuring structures - that is to say, as generating and organizing principles of practices and representations that can be objectively adapted to their goal without supposing that they consciously aim for them or master the operations necessary to reach them « ${ }^{15}$. The product of an individual trajectory, the habitus is the basis for individual and group practices, which aim to reproduce their positions. And agents reproduce their position in a field because their habitus makes possible the exteriorization of the interiorization 
of unconscious schemes of thought, perception, and action, ${ }^{16}$ observable in individual and collective practices. Thus, fields are the products of the habitus, while at the same time producing it. This thinking supposes that capital will be transmitted to certain heirs, who will be able to use it within the framework of existing social relations ${ }^{17}$ - in other words, to reproduce it over time. This is why analyzing so-called objective structures cannot be separated from analyzing the genesis of an individual's mental structures (the product of incorporating social structures) and from analyzing the genesis of these social structures themselves. ${ }^{18}$

Because the concept of habitus is so integral to the theory of fields, it has sometimes been seen as a simple theory of reproduction. But the concept can do more than simply explain reproduction patterns; it can also account for change, which happens when there is a "systematic mismatch between habitus and field, that is between the habitus and the requirements of a current situation ${ }^{19}$. The >mismatch can take the form of the arrival in a field of agents who are bearers of new dispositions and present different practices. A mismatch can also take place when the logic, politics, and structure of a field are modified following the appearance of a new set of socio-economic and historical circumstances, which the field channels into its functioning. In this case, the habitus can be modified by constantly participating in the field's activities.

\subsection{The state and public administration: historical products of struggles}

Even though Bourdieu did not himself use the word sstate until later in his career, several of his works address one aspect of it or another. When he decided to discuss the subject of the state directly, Bourdieu's ambition was to develop a model of the historical process of its development by focusing on the emergence, transformation, and reproduction of social groups over time. ${ }^{20}$ Even though his conception of the state, as expressed in his works, and explicitly in Sur l'État ${ }^{21}$, was not perfectly coherent, consulting the work of scholars interested in his legacy enables us to gain a better understanding of it as well as of public administration.

From the perspective of the theory of fields, the state, in whatever form, is a meta-field. "[It is] an en- semble of fields within which agents and categories of agents, governmental and nongovernmental, struggle over this peculiar form of authority consisting in the power to rule via legislation, regulations, administrative measures (subsidies, authorizations, restrictions, etc.) «. ${ }^{22}$ The state has emerged as the result of two simultaneous and related processes..$^{23}$ The first relates to the differentiation of the various social fields over time and their respective forms of capital, which is associated with the emergence of social groups, bearers of a specific habitus. This is how physical force, as a form of capital, has become concentrated and how groups have been created that specialize in legitimate violence, such as armies and police. ${ }^{24}$ The second process is that of appropriation and the gradual accumulation and concentration of the various forms of capital. In the European dynastic state, for example, power as well as material and symbolic resources (money, honours, titles, favours, etc.) became concentrated in the hands of a private person - the king - who, through a selective redistribution of capital, created or nurtured specific relationships to perpetuate his power. ${ }^{25}$

This concentration of capital, which makes the state a »central bank « of capital, ${ }^{26}$ guarantees the state's control over all other social fields. It influences the rates of exchange among the different forms of capital and thus determines the relationships among the agents that exchange them. ${ }^{27}$ This concentration of capital also gives the state the power to impose the so-called legitimate conceptions of the social world. ${ }^{28}$ This is why, among other things, state nominations have a universal value; as a result, the state gains a monopoly on symbolic violence. ${ }^{29}$ In this way, Bourdieu has amended Weber's famous formula to say that the state represents a monopoly of both physical and symbolic violence. ${ }^{30}$

Symbolic violence is committed through the internalization of categories of thought and systems of classification ${ }^{31}$ offered by the state as well as their reproduction, essentially through the school system. ${ }^{32}$ These cognitive structures, presented as granted, indicate the position of each agent in each field, including the state itself, leaving other agents with only the state thinking to think the state. ${ }^{33}$ The structures of this meta-field are embedded in the minds of its agents, thus reproducing the state in people's minds in the form of beliefs, by instilling a habitus, "which is the foundation of consen- 
sus over this set of shared evidence constitutive of (national) common sense ${ }^{34}$ As Hansen and Hammerslev ${ }^{35}$ noted, the word stater is not only descriptive but also prescriptive: it causes people to believe in the existence of the state. The state is part of the illusion that people must believe in if they want to participate in social life.

The state exists not only in the mind but also in the form of the agents and organizations that act on behalf of the state. In fact the state appears to be nothing more or less than a word that helps people "believe in the existence and unity of a number of scattered and divided ensemble of organs of rules which cabinets, ministries, departments, administrative directions, bureaus of this and that are «. ${ }^{36}$ These agents and organizations that act on behalf of the state evolve in different fields, the most pre-eminent of them being the administrative one. ${ }^{37}$ This field originated as the conception of the state shifted at a key moment in history, from its dynastic to its modern form, from an extension of the king and his household to an independent entity that transcends a person. ${ }^{38}$ This process was accompanied by the formation of a group of agents, devoted to a new, specialized activity: administering the state for the public good. This group of agents, collectively called the civil service, was built on the idea of protecting the general interest rather than the sking's house،, or a particular interest. The system of relationships among these agents' positions, their practices, and the institutions that are the historical products of their interactions, constitute the administrative field, and its "key stake is the representation of what service to the public should be «. ${ }^{39}$ Thus, the symbolic capital of the field, and of those agents of the administrative field who act on behalf of the state, is linked to its capacity to incarnate the general interest ${ }^{40}$ with a habitus that embodies loyalty and disinterest, values that are specific to public administration. ${ }^{41}$

The agents at the origin of the administrative field "are at the same time the producers of the state and its products « ${ }^{42}$ Through a discourse in which they described themselves as civil servants, ${ }^{43}$ these agents created their own positions by advocating practices that they were the most competent to carry out. They achieved a monopoly because they were the only ones able to exercise this form of symbolic power. ${ }^{44}$ Through their practices, agents of the administrative field produce documents - and the state. For example, practices for collecting taxes, which administrative institutions depend on to exist and develop, are justified by being protected from the enemy. For these practices to be properly enforced, the state will use, if necessary, its symbolic force. ${ }^{45}$

But it would be a mistake to believe that the only possible agents of the administrative field are civil servants. Any agent or organization that has an interest in determining what service to the public, or any related stake, should be, can become involved in the stakes of the administrative field. The presence of these sother agents reflects the relative autonomy of the administrative from the field of power. However, even though the field has a form of autonomy that derives from its specific activities and its particular type of capital, because administrative practices and institutions need the approval of politicians, it cannot be completely autonomous from their field. Other fields that are likely to influence the administrative field include unions and labour, as well as the economic fields, because of the links among their respective activities. That said, the stakes of any field can appear in more or less amended form ${ }^{46}$ in the administrative one.

As is the case for any field, the relative autonomy of the administrative field, the arrival of agents bearing a different habitus, and a change in the social environment are all sources of change in the structure of its positions. While a group of agents can be in a dominant position that is, able to impose its definition of what form service to the public should take - introducing any change will trigger struggles among its agents, resulting in the domination of a group or a change in the power structure, making the state, as a meta-field, the result of historical circumstances and struggles. This oscillation between stability and change explains the emergence, persistence, modification, and disappearance of the organizations, institutions, and practices of public administration in a coherent temporal, social, and political framework.

\section{A social and political approach to the history of public administration}

Considering the importance of the historical dimension in the theory of fields, historians of public admin- 
istration can benefit from using this approach in their works, in two complementary ways. First, this critical approach enables them to understand the position they occupy in the academic field, thus creating awareness that can lead them to question the intellectual categories they have used to study administrative history as well as their research practices. Second, the theory of fields provides the intellectual tools to conduct empirical studies that present generalizable conclusions. If this has been a goal more easily achieved in the social sciences, historical studies have struggled more with the possibility of reaching conclusions that can possibly be applied to several cases, often because of the absence of a clear theoretical framework. This section addresses these two dimensions and presents segments of analysis drawn from a developing research project on the history of Canadian federal public administration to show how the theory of fields can enlighten the historical understanding of public administration.

\subsection{Questioning intellectual categories and research practices}

The disciplines and specialties that study the state have to deal with the fact that the concepts they use have been developed by the state itself. This is the case for, among other disciplines, political science ${ }^{47}$ and policy analysis. ${ }^{48}$ It is also an issue for the history of public administration, which is dominated by studies that have used intellectual categories created by the state, such as the official structures and functions of public administration, and the institutional divisions of power. One historian has gone so far as to write that the discipline should be consistent with administrative practices and not make bureaucrats smile. ${ }^{49}$ This convergence with state thinking and the reproduction of it through research has consequences that prevent the production of an independent body of knowledge about administrative history.

At an intellectual level, scholars interested in administrative history have to deal with making the necessary and difficult break with state thinking, which is present in the most personal thought. ${ }^{50}$ The language used by the state, and imposed on all social fields, is the result of struggles, and so holds certain values. This is why Bourdieu has warned against using the state's vocabulary, the same categories as the state, they legitimize them, contribute more or less directly to their construction and existence, ${ }^{52}$ and systematize the knowledge about the state and its history. ${ }^{53}$ Thus, their work takes place within the framework of wider political strategies that impose a particular vision of the state, conform to the interests and values of those state agents who produce those strategies, ${ }^{54}$ and cannot lead to real knowledge of its history.

Because the state exists in two areas - in the brain and in material structures - historians of public administration also encounter difficulties at the institutional level, more specifically in the institutional organization of academia. The official division of responsibilities between the political institutions and public administration, as well as within each of them, is reflected in the academic field. This is how, for example, the study of political science, public administration, and public policy has been traditionally divided into separate disciplines. Historians of public administration, particularly, may be more affected by the reproduction of state structures in academia because they find themselves at the intersection of several specialties, such as the history of political thought, the history of administrative institutions and practices, and social and personnel history. ${ }^{55}$ This fragmentation of history into several disciplines, the monopoly that their respective specialists claim over them, and, as a result, the difficulty historians have in moving with the same ease in each of them, make the study of administrative history more difficult than other subjects that are made up of a single discipline.

Because archival research is so important for historians of public administration, they face an additional obstacle in their scholarly efforts that other scholars may not have to deal with. Not only do they use the intellectual categories created by the state and its agents, but they also use primary sources that have been created by these same agents, using these same categories. Since the use of the first censuses and budgets at the turn of the 13th century, the state has concentrated information capital. ${ }^{56}$ Agents of public administration produce information about the state's view of society and itself, organize and conserve it in the form of archives, and distribute it to other fields as the official, legitimate, and only information recognized by the state, thus imposing its view across society. As Potin, among others, 
succinctly formulated it, "The state becomes constructed because archives are classified $« .{ }^{57}$

Archives are the permanent incarnation of state thought and a central tool of symbolic state violence. Their importance in this process is observed in the efforts that the state expends to preserve them, sometimes even making them inaccessible to protect state secrets or the privacy of the agents involved. Thus, when researchers use administrative archives, they once again legitimize the domination of the state. In fact, historians have encouraged the production of state-related archival documents, which Bourdieu and his collaborators have called 'documentary inflation.${ }^{58}$ Historians' need for information has created a cycle whereby their own work stimulates public administration to produce more information, which then confirms the domination of the state. Being aware of this reality shows that historians do not conduct their archival studies in a >power vacuum ${ }^{59}$

Despite these difficulties, however, it is possible to develop a social and political history of public administration that is free from state thinking. Starting with the notion of radical doubt, ${ }^{60}$ Bourdieu has developed three types of research strategies to deal with the difficulties linked to studying this field. ${ }^{61}$ The first consists of studying actual, regular bureaucratic practices rather than the official discourse of the state or so-called objective constituents, such as organizational structures and formal descriptions of professional responsibilities. Research should focus on how the behaviour and practices associated with public administration (laws, rules, administrative regulations, etc.) are created and move away from what Bourdieu calls ınaïve questions, such as "Who governs? «. ${ }^{62}$ The second strategy suggests analysing the anthropological dimensions of public administration, such as calendars. The third and most important research strategy, which Bourdieu ${ }^{63}$ claims is the most powerful tool for establishing a break with state thinking, is reconstructing the genesis of the state by creating a sociological history of the agents and institutions that make up the state and its administration. This process allows reconstructing the conflicts that were at their roots and thus questioning how the state presents them.

This perspective on research has led Dubois ${ }^{64}$ to identify five questions to guide the study of policy fields. These same questions can be adapted to the study of the history of public administration to formulate hypothe- ses about the persistence of, and changes in, the practices and institutions of the field as well as their genesis.

1) What is the stake? The first question to ask when conducting research on the administrative field is about its key stake. It is not possible to answer this question by using the mental categories of the state or the sofficial story told by administrative archives. Instead, researchers must begin their investigation on the basis that what is most at stake in this field is determining what the representation of the service to the public should be. From there, keeping in mind that the field's structure is constantly moving, the goal is to identify the secondary stakes and how agents become involved in struggles.

2) What are the limits of the field? Determining the temporal and spatial limits of the administrative field allows identifying the agents who belong to it and who can participate in its struggles or have the potential to. Defining these limits, which can be done through empirical research and using different approaches, ${ }^{65}$ is particularly important because these limits are themselves at stake in the field: they determine who can participate in the activities and conflicts of the administrative field.

3) What is the autonomy of the field? By moving the focus of administrative history to the empirical reality of the administrative field, the theory of fields allows taking into account the influence of not only the agents and organizations traditionally associated with public administration, such as civil servants and ministries or departments, but also those that may not be officially or obviously associated with what is at stake. Determining the level of autonomy of the field permits explaining the true logic that governs it and its conflicts over what is at stake.

4) What are the opposing principles that structure the field? Although each case is different, some recurring opposing principles among agents can be identified. ${ }^{66}$ In the administrative field, some agents, such as senior civil servants, who are not unionized, may oppose those who are associated with defending particular interests, such as union representatives. Whatever the opposition, it is important to identify it, or them, because this balance of power is central to determining the evolution of the field and its functioning.

5) What is the outcome of the opposition between the agents? The theory of fields can best be understood when processes are studied in the middle and long terms. ${ }^{67} \mathrm{Op}$ positions between agents of the administrative field are 
the products of history, and their outcomes determine the practices and institutions that set up future stakes and conflicts. Practices and institutions put in place at the outcome of a struggle incarnate the values of the dominant group in the field, and they can be analyzed as instruments of reproduction by studying what they do, what they produce, and the influence they exercise. ${ }^{68}$

As these research strategies and questions show, using the theory of fields enables overcoming the intellectual and institutional difficulties faced when studying the history of public administration. By adopting a critical and empirical approach, researchers can break away from the state's conceptualization of public administration and go beyond the dictates of their academic specialty. They can also identify the categories used by the state in creating its archives and understand the political context in which those categories have been created. By reconstructing the genesis of the administrative field as well as its stakes and struggles, researchers are then in a position to write about the phenomenon of persistence and change in public administration.

\subsection{Applying the theory of fields: the history of the introduction of the merit system in the Canadian federal civil service}

To illustrate the perspective that the theory of fields can provide on the history of public administration, this section presents a segment of analysis drawn from a developing research project on the early history of the merit system in the Canadian federal public administration; it is based on secondary sources that have examined the topic from historical and political perspectives. Applying the Bourdieusian approach to this period is particularly useful because that time marks the beginning not only of the merit system, but also of the country's administrative agents and institutions, and their system of relationships. This short study does not provide a detailed analysis of the case; that is beyond the scope of this article. Rather, by using the core concepts of the theory of fields, this section suggests that by examining the genesis of the administrative field in Canada, it is possible to understand the introduction of the merit principle as the result of a disruption of a stable period in the field of power. This theory, as this section shows, presents the advantage of explaining a phenomenon that so far has been described in its context, by the traditional approach to the subject.

From Canada's independence from the British Crown in $1867^{69}$ until 1917, appointments to the country's federal civil service adhered largely to a system of patronage. Patronage is "the use of the administration's resources with a view to bringing logistic support to a party and privileged help to those who support it [...]. The control of the administration or of some segments of it becomes for the party an essential source of supply, a means to maintain a tangible motivation in its members «. ${ }^{70} \mathrm{In}$ the Canadian version of this system, appointments to the civil service were made on the basis of the political affiliations of the candidates, whether it was to fill the position of a postmaster, a judge, or Queen's Counsel. ${ }^{71}$ Even though the candidates' suitability may have been taken into consideration, positions were offered to those who had supported the election of the governing party. Politicians used the appointments as possible or actual rewards for their own benefit and those of their party.

The traditional perspective on the first 50 years of the merit system in Canadian public administration presents this system as the answer to problems posed by the patronage system. At the turn of the 19th century, following the rise of the political economy movement, according to which "politics, society and the economy could be managed through rational knowledge, observable laws, and predictive patterns «, ${ }^{72}$ and because of the disdain among the country's political elite for the American spoils system, ${ }^{73}$ patronage came under criticism because it was considered to be immoral and a source of administrative inequity and inefficiency. This perception reached a peaked during the First World War, when newspapers were reporting on the flaws in the Canadian army's training and equipment, which were said to be due to "the government's apparent favouritism, corruption, and general mismanagement, especially in the distribution of war contracts «. ${ }^{74}$ On the other hand, the merit system - the mechanism by which »all citizens should have a reasonable opportunity to be considered for employment in the public service, and ... selections must be based exclusively on qualification or fitness for the job « ${ }^{75}$ - represented a better way to provide the public administration with employees and promote them over the course of their careers. Thus, by establishing a connection among social factors and a po- 
litical discourse, and the solution that political and administrative institutions found for them, the traditional approach considers the introduction of the merit system to be a technically and administratively so-called rational response to an administrative issue that was no longer socially acceptable. This analysis does provide contextual elements for the emergence of the merit system in the Canadian public administration. Yet, despite its apparent coherence, it fails to explain either the actual reasons why the merit system was eventually adopted or the 50-year gap between its first being mentioned as a concept in the federal Civil Service Act of 1868 and finally becoming an administrative institution.

Seen from the perspective of the theory of fields, the institutionalization of the merit system in the Canadian federal administration was less about the introduction of a universal, technically neutral and rational answer to an administrative issue made unacceptable under specific social and political influences than it was about the emancipation of the administrative field, with the emergence of a group of agents bearing a new form of capital. In 1867, there was little differentiation between the public and private spheres in Canadian society, partly because of the country's recent independence. This was reflected, among other things, in the absence of a clear separation between the field of power and the administrative field. One of the most important manifestations of this was the system of partisan nomination to the civil service. Because ministers (elected officials at the head of each administrative unit) had the last word in the hiring process, it was political capital - that is, symbolic capital based on belief and recognition, or, more precisely, the operations through which agents confer on someone or something powers that give it recognition ${ }^{76}$ - that primarily determined employment opportunities. Those seeking employment acquired this form of capital by contributing money and time to the campaign activities of a political party or its candidates; once an election was over, this political capital could be exchanged for economic capital in the form of access to a position in public administration. ${ }^{77}$

Between 1868 and 1917, the agents of the field of power held a discourse that supported either the patronage system or the merit one. Their views reflected their positions in this field, which related to their status tive assembly). While members of the government tried to maintain the patronage system in place and thereby benefit from the capital it represented, the members of the opposition, in their efforts to control and defeat the government, would hold a discourse promoting the merit system. Yet, a change of governing party, following an election, made both groups of agents adopt the opposite stance, as the new governing party demanded the rewards that it had previously been denied..$^{78}$ Because all politicians took advantage of patronage, or could potentially do so, the elements of the merit system that had been institutionalized showed that the opposition was fulfilling its function as a critic of the government, and yet this institutionalization was weak enough that the patronage system could still function. This is why more or less significant pieces of a merit system were introduced into the Canadian federal civil service over a period of 50 years, but without ever becoming a fully functioning system. ${ }^{79}$ In 1868, Parliament adopted the first piece of legislation relating to the civil service; it required candidates to take a ppass or fail entry examination, to be administered at the behest of deputy ministers. ${ }^{80}$ But this legislation did not actually meet the objectives of a merit system: it seems that, between 1875 and 1880, only one candidate was required to take the exam. ${ }^{81}$ By 1878 , the act was considered a dead letter, and Prime Minister J. A. Macdonald declared that introducing neutrality into the civil service would be akin to taking Canada back to "the age of Adam and Eve before the apple ${ }^{82} \mathrm{~A}$ few years later, in 1882, the legislation was amended to stipulate that a candidate for a position in the civil service had to demonstrate the "requisite knowledge and ability to enter on discharge of his official duties «. ${ }^{83}$ Yet the new requirements applied only to positions in the inner civil service - that is, those positions located in the national capital region around Ottawa, which represented onesixth of the civil service. In 1908, after having pressured the Liberal government to create a Civil Service Commission, a neutral and independent organization responsible for the management of careers in the civil service, the Conservative party changed its discourse on the topic once it had arrived in a governing position. By 1911, the Commission disposed of a largely illusory authority. ${ }^{84}$

It was in 1917, shortly after the federal election and a change in the structure of the field of power, that the merit system achieved genuine institutionalization, 
with the arrival of a new group of agents in the administrative field. That year, a coalition of political parties was called to form the government - remembered as the Union government, a rare occurrence in a country with a bipartisan, 'first-past-the-post e electoral system, thus modifying the power relationships among elected offcials. Soon the new government found itself unable to make partisan nominations in the civil service, ${ }^{85}$ and the opposing parties could not agree on whom to appoint, because political circumstances now prevented the old patronage-based mode of nomination from functioning. The resulting institutionalization of institutions and practices enabled individuals to be hired on the basis of merit, rather than political affiliation, and allowed the political and administrative fields to function, albeit in a different type of relationship, whereby the administrative field had gained a new autonomy. In 1918, Parliament adopted new legislation that formally introduced the merit principle, applying it to all 40,000 positions in the civil service. ${ }^{86}$ And the following year, a job classification system, necessary to determine the requirements for each position, was instituted under the responsibility of the Civil Service Commission. These elements were the crystallization of a political compromise, in parallel with the emergence of a group of professional civil servants, who would eventually become involved in struggles of their own in the newly independent administrative field. No longer was these agents' legitimacy based on adherence to a political party, or political family; they became the bearers of a habitus anchored in the notion of public good, in a more autonomous administrative field.

\section{Conclusion}

The interplay among the core concepts of French sociologist Pierre Bourdieu's theory of fields - capital, field, and habitus - offers a reconceptualization of the study of administrative history that integrates historical, social, and political elements. The administrative field, one of the components of the state, appeared when a group of agents, devoted to the activities linked to the administration of the public interest, emerged. The administrative organizations, institutions, and practices of ministrative history, are the institutionalized outcome of struggles that have taken place in the field among agents who, using their capital, attempted to impose their conceptualization of what service to the public should be. Persistence and change in these organizations, institutions, and practices reflect the stability and modification of the power relationships among the positions occupied by agents of the administrative field.

By understanding the logic of the historical process from which the state and the administrative field emerged, Bourdieu's theory of fields offers several possibilities for scholars interested in studying the historical dimensions of public administration. First, it is a powerful, self-reflecting tool for examining how the intellectual frameworks they have been using and their research practices contribute to the reproduction of the state. Once they realize this, historians of public administration can establish the necessary critical distance with their object of study and, thus, be in a position to produce an understanding of administrative history that goes beyond formal structures and functions. Second, this approach allows looking at objects that are traditionally at the core of the study of administrative history, such as formal institutions, functions, and employees, in their historical, social, and political context. By focusing on actual practices, and advocating an empirical approach to research, the theory of fields explains the historical reality of public administration because it goes beyond simply inserting certain facts into a narrative or interpretative framework. ${ }^{87}$ Third, the theory of fields permits identifying unique historical experiences, while revealing characteristics common to a variety of cases. ${ }^{88}$ This was shown earlier by the short analysis of the early history of the merit system in the Canadian federal administration. In that case, the development over a period of half a century of a system of management and organization of the civil service based on the merit principle was closely linked to the emergence of a group of professional public servants, as observed elsewhere. ${ }^{89}$ Yet - and this appears to be a Canadian particularity - the leading force behind the formation of this group was not the administrative agents themselves, but agents of the field of power. Once federal politicians found themselves in a position where they could no longer control the capital represented by the civil service, the merit system and its associated practices became institutionalized. 
This example, as well as the theoretical analysis that preceded it, mark a first step in developing a social and political approach to the history of public administration. This article will hopefully be the point of departure for other studies that explore single jurisdictions, over more or less long periods of time, and eventually produce both interdisciplinary and comparative works..$^{90}$ The history of administrative reforms appears to be a particularly fruitful ground for this type of study. Administrative reforms have often been studied as the deliberate introduction of change into public administration, aiming to replace established institutions and practices; yet the factors that explain their success in modifying an established order, or more often the lack thereof, have not been fully understood.

The theory of fields suggests that the answer to the persistence of these administrative organizations and practices over the years, and their resistance to change, lies in the reproduction of the structure of power of the administrative field. The proximity of the field of pow- er and the administrative field makes it possible to hypothesize that a stable political order renders it difficult to make administrative reforms. Because the structure of the administrative field is influenced by the structure of the field of power, the persistence of a specific distribution of capital in the field of power may lead to a similar effect in the administrative field. This suggests that administrative reforms may be more difficult to introduce in jurisdictions where the same political party, or a coalition of the same political parties, controls the government for a substantial period of time and that long-standing governments may have fewer chances to introduce successful reforms, whatever their intentions may be. While it is beyond the scope of this article to verify these statements, it is certain that historians who use Bourdieu's approach to study administrative reforms or other aspects of public administration will bring to light the social and political tensions that lie beneath the manifestation of any administrative fact. 
A N S A R T, Pierre: Les sociologies contemporaines, Paris 1990. B A N O U B , David: „The Patronage Effect: Civil Service Reforms, Job Seeking, and State Formation in Victorian Canada", unpublished Doctoral Dissertation, Carleton University, Department of History, Carleton 2013. B O N , Frédéric / S C H E M E I L, Yves: »La rationalisation de l'inconduite. Comprendre le statut du politique chez Bourdieu«, in: Revue française de science politique 30 (1980), p. 1198-1228. B O U R D IE U, Pierre: La distinction, Paris 1976. - Le sens pratique, Paris 1980. - "La représentation politique. Éléments pour une théorie du champ politique«, in: Actes de la recherche en sciences sociales 36-37 (1981), p. 13-24. - "La force du droit. Éléments pour une sociologie du champ juridique«, in: Actes de la recherche en sciences sociales 64 (1986), p. 3-19. • Choses dites, Paris 1987. • „Esprits d'État. Genèse et structure du champ bureaucratique«, in: Actes de la recherche en sciences sociales 96 (1993), p. 49-62. • "De la maison du roi à la raison d'État: un modèle de la genèse du champ bureaucratique«, in: Actes de la recherche en sciences sociales 118 (1997), p. 55-68. • Méditations pascaliennes, Paris 1997. - Practical Reason. On the Theory of Action, Stanford (CA) 1998. - »Modstridende interesser i staten«, in: Praktiske Grunde 1-2 (2010), p. 121-134. • Sur l'État. Cours au Collège de France (1989-1992), Paris 2012. • - / C H R I S T I N, Olivier / W I L L, PierreÉtienne: "Sur la science de l'État", in: Actes de la recherche en sciences sociales 133 (2000), p. 3-11. • - / C H R I S T I N , Rosine: »La construction du marché. Le champ administratif et la production de la spolitique du lodgement «, in: Actes de la recherche en sciences sociales 81-82 (1990), p. 65-85. - - / P A S S E R O N, Jean-Claude: La reproduction, Paris 1970. • - / W A C Q U A N T, Loïc J. D.: Réponses. Pour une anthropologie réflexive, Paris 1992. C A M P B E L L, Robert A.: »Liquor and Liberals: Patronage and Government Control in British Columbia 1920-1928«, in: British Columbia Studies 77 (1988), p. 30-53. C A R O, Jean-Yves: "La sociologie de Pierre Bourdieu: Éléments pour une théorie du champ politique«, in: Revue française de science politique 30 (1980), p. 1171-1197. C A T L A W, Thomas J. / H U, Qian: „Legitimacy and Public Administration. Constructing the American Bureaucratic Fields", in: American Behavioral Scientist 53 (2009/10), p. 458-481. C H A M P AG N E , Patrick: »La contribution de l'État à la domination«, in: Swiss Political Science Review 20 (2014), p. 4-8. D É L O Y E, Yves: Sociologie historique du politique, Paris 1996. D I O N , Stéphane: "La politisation des administrations publiques: éléments d'analyse stratégique«, in: Canadian Public Administration 29 (1986), p. 95-117. D U B O I S, Vincent: "La sociologie de l'action publique, de la socio-histoire à l'observation des pratiques«, in: Dany Trom, Pascale Laborier (eds.), Historicités de l'action publique, Paris 2003, p. 347-364. • "L'action de l'État, produit et enjeu des rapports entre espaces sociaux «, in: Actes de la recherche en sciences sociales 201-202 (2014), p. 13-25. • "L'État, l'action publique et la sociologie des champs«, in: Swiss Political Science Review 20 (2014), p. 25-30. E M I R B A Y E R, Mustafa / J O H N S O N , Victoria: "Bourdieu and Organizational Analysis«, in: Theory and Society 37 (2008), p. 1-44. F O U R N I E R, Marcel: "L'institutionnalisation des sciences sociales au Québec«, in: Sociologie et sociétés 5/1 (1973), p. 27-58. G E O R G A K A K I S, Didier: „L'administration de I'Union européenne à la croisée des chemins«, in: Revue française d'administration publique 133 (2010), p. 5-16. - (ed.), Le champ de l'Eurocratie. Une sociologie politique du personnel de l'UE, Paris 2011. • "Quel pouvoir pour „l'eurocraties? Éléments sur un nouveau champ bureaucratique transnational«, in: Savoir/Agir 19 (2012), p. 49-59. • - / L A S S A L L E, Marine de: "Genèse et structure d'un capital institutionnel européen. Les très hauts fonctionnaires de la Commission européenne«, in: Actes de la recherche en sciences sociales 166-167 (2007), p. 38-53. G I N G R A S, Yves: "L'institutionnalisation de la recherche en milieu universitaire et ses effets«, in: Sociologie et sociétés 23/1 (1991), p. 41-54. G O R S K I,
Philip S.: „Bourdieusian Theory and Historical Analysis. Maps, Mechanisms, and Methods", in: Philip S. Gorski (ed.), Bourdieu and Historical Analysis, Durham, London 2013, p. 327-366. H A N S E N , Jens Arnholtz / H A M M E R S L E V, Ole: "Transcended Power of the State: The Role of Actors in Pierre Bourdieu's Sociology of the State", in: Distinktion. Journal of Social Theory 14 (2013), p. 42-64. - - / - , "Bourdieu og Staten«, in: Praktiske Grunde 1-2 (2010), p. 11-31. H E R O N , Craig / S I E M I A T Y C K I, Myer: "The Great War, the State, and Working-Class Canada", in: Craig Heron (ed.), The Workers' Revolt in Canada 19171925, Toronto 1998, p. 11-42. H O D G E T T S, John Edwin: The Canadian Public Service. A Physiology of Government 1867-1970, Toronto 1973. INTERNATIONAL INSTITUTE OF ADMINISTRATIVE SCIENCES: List of the Publications of the Project group "History of Public Administration«, in: http://www.iias-iisa.org/groups/projectgroups/pg-i-history-of-public-administration/publications/ (date: March 15, 2016). J E N K I N S, Richard: Pierre Bourdieu, London 1992. K E R N A G H A N , Kenneth / S I E G E L, David: Public Administration in Canada. A Text, Scarborough 1999. L A M O U R O U X, Christian: "Qualification des hommes et procedures administratives«, in: Actes de la recherche en sciences sociales 133 (2000), p. 26-31. L E N O I R, Rémi: "Savoir et sciences de l'État: généalogie et démographie«, in: Actes de la recherche en sciences sociales 133 (2000), p. 96-97. • „Bourdieu et l'État», in: Savoir/Agir 19 (2012), p. 117-126. • "L'État selon Pierre Bourdieu«, in: Sociétés contemporaines 87 (2012), p. 123-154. • "L'État selon Pierre Bourdieu: Une monopolisation de l'universel«, in: Swiss Political Science Review 20 (2014), p. 9-13. M C D O N O U G H, Peggy: "Habitus and the Practice of Public Service«, in: Work, Employment and Society 20 (2006), p. 629-647. M Ü L L E R, Philipp: »Archives and History: Towards a History of sthe Use of State Archives in the 19th Century«, in: History of the Human Sciences 24/6 (2013), p. 27-49. P O T I N , Yann: „L'État et son trésor «, in: Actes de la recherche en sciences sociales 133 (2000), p. 48-52. R A A D S C H E L D E R S, Jozef C. N.: Handbook of Administrative History, New Brunswick (NJ) 2000. R A S M U S S E N, Kenneth A. / JU ILLET, Luc: "The Origins of Merit in Canada", in: Onkar Prasad Dwivedi, Tim Mau, Byron Sheldrick (eds.), The Evolving Physiology of Government. Canadian Public Administration in Transition, Ottawa 2009, p. 74-96. R O U X , Sébastien / et al.: „Penser l'État“, in: Actes de la recherche en sciences sociales 201-202 (2014), p. 4-10. S T E I N M E T Z, George: „Bourdieu, Historicity, and Historical Sociology«, in: Cultural Sociology 5 (2011), p. 45-66. • "État-mort, État-fort, État-empire", in: Actes de la recherche en sciences sociales 201-202 (2014), p. 112-119. T H U I L L I E R , Guy: „Pour une théorie générale de l'histoire de la bureaucratie (suite)«, in: La Revue administrative 292 (1996), p. 381-389. V A U G H A N , Diane: "Bourdieu and Organization: The Empirical Challenge«, in: Theory and Society 37 (2008), p. 65-81. W A C Q U A N T, Loïc J. D.: „From Ruling Class to Field of Power: An Interview with Pierre Bourdieu on La Noblesse d'État«, in: Theory, Culture \& Society 10/3 (1993), p. 19-44. W A I T E , Peter B.: Canada 1874-1896: Arduous Destiny, Toronto 1971. 
* The author wishes to thank the anonymous reviewer, the editors of administory, as well as Pr. Dagmar Soennecken and Pr. Thaddeus Hwong for their useful comments and suggestions at different phases of the preparation of this article.

1 Loïc J. D. Wacquant, »From Ruling Class to Field of Power: An Interview with Pierre Bourdieu on La Noblesse d'État«, in: Theory, Culture \& Society 10/3 (1993), p. 19-44, at p. 41.

2 For examples of these works, see the Yearbook of European Administrative History, published between 1989 and 2008 under the editorship of Erk Volkmar Heyen; International Institute of Administrative Sciences, List of the Publications of the Project group »History of Public Administration«, in: http://www.iias-iisa.org/groups/ project-groups/pg-i-history-of-public-administration/publications/ (date: March 15, 2016); as well as the extensive bibliography prepared by Jozef C. N. Raadschelders, Handbook of Administrative History, New Brunswick (NJ) 2000.

3 Yves Déloye, Sociologie historique du politique, Paris 1996, p. 23-27.

4 E. g. Didier Georgakakis, "L'administration de I'Union européenne à la croisée des chemins «, in: Revue française d'administration publique 133 (2010), p. 5-16; Didier Georgakakis (ed.), Le champ de I'Eurocratie. Une sociologie politique du personnel de I'UE, Paris 2011; Didier Georgakakis, „Quel pouvoir pour sl'eurocraties? Éléments sur un nouveau champ bureaucratique transnational«, in: Savoir/Agir 19 (2012), p. 49-59; Didier Georgakakis, Marine de Lassalle, »Genèse et structure d'un capital institutionnel européen. Les très hauts fonctionnaires de la Commission européenne«, in: Actes de la recherche en sciences sociales 166-167 (2007), p. 38-53.

5 Sébastien Roux et al., "Penser l'État», in: Actes de la recherche en sciences sociales 201-202 (2014), p. 4-10, at p. 5.

6 The goal of this section is not to provide an extensive and critical review of Bourdieu's conception of the state; others have already done so. See, among others, the special issues of the Actes de la recherche en sciences sociales 201-202 (2014) and the Swiss Political Science Review 20/1 (2014).

7 George Steinmetz, "Bourdieu, Historicity, and Historical Sociology«, in: Cultural Sociology 5 (2011), p. 45-66, at p. 51.

8 Ibidem, p. 56.

9 Pierre Bourdieu, Loïc J. D. Wacquant, Réponses. Pour une anthropologie réflexive, Paris 1992, p. 72.

10 Richard Jenkins, Pierre Bourdieu, London 1992, p. 86.

11 Pierre Bourdieu, Méditations pascaliennes, Paris 1997, p. 25.

12 Marcel Fournier, "L'institutionnalisation des sciences sociales au Québec«, in: Sociologie et sociétés 5/1 (1973), p. 27-58, at p. 27.

13 Jenkins, Pierre Bourdieu, p. 85.

14 Pierre Bourdieu, La distinction, Paris 1976, p. 146.

15 Pierre Bourdieu, Le sens pratique, Paris 1980, p. 88-89; personal translation.

16 Pierre Ansart, Les sociologies contemporaines, Paris 1990, p. 42.

17 Jean-Yves Caro, "La sociologie de Pierre Bourdieu: Éléments pour une théorie du champ politique«, in: Revue française de science politique 30 (1980), p. 1171-1197, at p. 1178.

18 Pierre Bourdieu, Choses dites, Paris 1987, p. 24.

19 Steinmetz, »Bourdieu, Historicity, and Historical Sociology«, p. 52.

20 Jens Arnholtz Hansen, Ole Hammerslev, "Transcended Power of the State: The Role of Actors in Pierre Bourdieu's Sociology of the State«, in: Distinktion. Journal of Social Theory 14 (2013), p. 42-64, at p. 48.

21 Pierre Bourdieu, Sur l'État. Cours au Collège de France (1989-1992), Paris 2012.

22 Bourdieu/Wacquant, Réponses, p. 111.

23 Rémi Lenoir, "Bourdieu et l'État», in: Savoir/Agir 19 (2012), p. 117126, at p. 120; Rémi Lenoir, »L'État selon Pierre Bourdieu«, in: So- ciétés contemporaines 87 (2012), p. 123-154, at p. 136-137; Rémi Lenoir, "L'État selon Pierre Bourdieu: Une monopolisation de l'universel«, in: Swiss Political Science Review 20 (2014), p. 9-13.

24 Jens Arnholtz Hansen, Ole Hammerslev, »Bourdieu og Staten«, in: Praktiske Grunde 1-2 (2010), p. 11-31, at p. 16.

25 Pierre Bourdieu, »De la maison du roi à la raison d'État: un modèle de la genèse du champ bureaucratique «, in: Actes de la recherche en sciences sociales 118 (1997), p. 55-68, at p. 62.

26 Bourdieu, Sur l'État, p. 196.

27 Bourdieu/Wacquant, Réponses, p. 90.

28 Lenoir, "L'État selon Pierre Bourdieu«, p. 129.

29 Pierre Bourdieu, "La force du droit. Éléments pour une sociologie du champ juridique«, in: Actes de la recherche en sciences sociales 64 (1986), p. 3-19, at p. 12-14.

30 Bourdieu, Sur l'État, p. 22-23.

31 Pierre Bourdieu, Rosine Christin, "La construction du marché. Le champ administratif et la production de la spolitique du logement«", in: Actes de la recherche en sciences sociales 81-82 (1990), p. 65-85.

32 Pierre Bourdieu, Jean-Claude Passeron, La reproduction, Paris 1970.

33 Pierre Bourdieu, "Esprits d'État. Genèse et structure du champ bureaucratique«, in: Actes de la recherche en sciences sociales 96 (1993), p. 49-62, at p. 49.

34 Pierre Bourdieu, Practical Reason. On the Theory of Action, Stanford 1998, p. 54.

35 Hansen/Hammerslev, »Bourdieu og Staten«, p. 13.

36 Loïc J. D. Wacquant, »From Ruling Class to Field of Power: An Interview with Pierre Bourdieu on La Noblesse d'État», in: Theory, Culture \& Society 10/3 (1993), p. 19-44, at p. 41.

37 Hansen/Hammerslev, »Bourdieu og Staten«, p. 13.

38 Ibidem, p. 23.

39 Pierre Bourdieu, Olivier Christin, Pierre-Étienne Will, "Sur la science de l'État«, in: Actes de la recherche en sciences sociales 133 (2000), p. 3-11, at p. 8; personal translation.

40 Georgakakis/Lassalle, "Genèse et structure«, p. 39.

41 Bourdieu/Christin/Will, "Sur la science de l'État«, p. 4. In Bourdieu's works (among others Bourdieu, "De la maison du roi à la raison d'État«), as well as in those of some other authors, the terms "administrative field", "state field «, »bureaucratic field ", "public service», and "field of state institutions « seem to be used interchangeably. Because the concept of bureaucracy refers to a mode of organization found in both the public and the private sectors, it seems appropriate to use the term "administrative field« to designate the set of relationships organized around the stake of the definition of what service to the public should be.

42 Lenoir, "L'État selon Pierre Bourdieu«, p. 127; personal translation.

43 Hansen/Hammerslev, »Bourdieu og Staten«, p. 22.

44 Ibidem.

45 Patrick Champagne, "La contribution de l'État à la domination«, in: Swiss Political Science Review 20 (2014), p. 4-8, at p. 7.

46 Pierre Bourdieu, "Modstridende interesser i staten«, in: Praktiske Grunde 1-2 (2010), p. 121-134, at p. 130.

47 Frédéric Bon, Yves Schemeil, "La rationalisation de l'inconduite. Comprendre le statut du politique chez Bourdieu«, in: Revue française de science politique 30 (1980), p. 1198-1228.

48 Vincent Dubois, "La sociologie de l'action publique, de la socio-histoire à l'observation des pratiques«, in: Dany Trom, Pascale Laborier (eds.), Historicités de l'action publique, Paris 2003, p. 347-364; Vincent Dubois, "L'action de l'État, produit et enjeu des rapports entre espaces sociaux«, in: Actes de la recherche en sciences sociales 201-202 (2014), p. 13-25; Vincent Dubois, "L'État, l'action publique et la sociologie des champs«, in: Swiss Political Science Review 20 
(2014), p. 25-30.

49 Guy Thuillier, "Pour une théorie générale de l'histoire de la bureaucratie (suite)«, in: La Revue administrative 292 (1996), p. 381-389, at p. 381.

50 Bourdieu, »Esprits d'État«, p. 49.

51 Ibidem.

52 Ibidem, p. 50.

53 Rémi Lenoir, "Savoir et sciences de l'État: généalogie et démographie«, in: Actes de la recherche en sciences sociales 133 (2000), p. 96-97, at p. 96.

54 Bourdieu, »Esprits d'État», p. 50.

55 Ibidem, p. 51-52.

56 Ibidem, p. 54.

57 Yann Potin, "L'État et son trésor «, in: Actes de la recherche en sciences sociales 133 (2000), p. 48-52, at p. 51.

58 Bourdieu/Christin/Will, "Sur la science de l'État«, p. 5.

59 For a study of the political dimensions of historians' state archival studies in the context of the 19th-century kingdom of Bavaria, see Philipp Müller, »Archives and History: Towards a History of sthe Use of State Archives in the 19th Century«, in: History of the Human Sciences 24/6 (2013), p. 27-49, at p. 41.

60 Bourdieu, »Esprits d’État«, p. 50.

61 Lenoir, »Bourdieu et l'État«, p. 121-122.

62 Wacquant, »From Ruling Class to Field of Power«, p. 41.

63 Bourdieu, »Esprits d'État«, p. 51.

64 Dubois, »L'État, l'action publique et la sociologie des champs«, p. 2729.

65 For examples of these approaches, see, among others, ibidem, p. 28.

66 Ibidem.

67 Georgakakis, »Quel pouvoir pour ıl'eurocratie«?«, p. 55.

68 Roux et al., „Penser l'État«, p. 5.

69 The country achieved complete independence in 1982, when it received the right to modify its constitution without an act of the British Parliament.

70 Stéphane Dion, "La politisation des administrations publiques: éléments d'analyse stratégique«, in: Canadian Public Administration 29 (1986), p. 95-117, at p. 105; personal translation.

71 Robert A. Campbell, "Liquor and Liberals: Patronage and Government Control in British Columbia 1920-1928«, in: British Columbia Studies 77 (1988), p. 30-53, at p. 31.

72 David Banoub, "The Patronage Effect: Civil Service Reforms, Job Seeking, and State Formation in Victorian Canada«, unpublished Doctoral Dissertation, Carleton University, Department of History, Carleton 2013, p. 23.

73 For an analysis of the 19th-century federal parliamentary debates on the question of the non-partisan nature and permanence of the civil service, see Banoub, »The Patronage Effect«, p. 37, p. 54.

74 Craig Heron, Myer Siemiatycki, "The Great War, the State, and Working-Class Canada«, in: Craig Heron (ed.), The Workers' Revolt in Canada 1917-1925, Toronto 1998, p. 11-42, at p. 16.

75 Kenneth Kernaghan, David Siegel, Public Administration in Canada. A Text, Scarborough 1999, p. 682-683.

76 Pierre Bourdieu, "La représentation politique. Éléments pour une théorie du champ politique«, in: Actes de la recherche en sciences sociales 36-37 (1981), p. 13-24, at p. 14.

77 As opposed to American practice, the election of a new federal government would not lead to a complete schanging of the guards in the civil service.

78 Campbell, »Liquor and Liberals«, p. 31.

79 For a detailed chronology of the legislation and formal practices as- sociated with the introduction of the merit system in the Canadian federal civil service, see Kenneth A. Rasmussen, Luc Juillet, "The Origins of Merit in Canada«, in: Onkar Prasad Dwivedi, Tim Mau, Byron Sheldrick (eds.), The Evolving Physiology of Government. Canadian Public Administration in Transition, Ottawa 2009, p. 74-96.

80 John Edwin Hodgetts, The Canadian Public Service. A Physiology of Government 1867-1970, Toronto 1973, p. 265. The exam evaluated the age, health, and morality of the candidates, who also had to provide letters of reference testifying to their political allegiance: see Banoub, »The Patronage Effect«, p. 35.

81 Ibidem, p. 36.

82 Peter B. Waite, Canada 1874-1896: Arduous Destiny, Toronto 1971, p. 20.

83 Quoted in Banoub, »The Patronage Effect», p. 68.

84 Campbell, »Liquor and Liberals«, p. 31.

85 Hodgetts, The Canadian Public Service, p. 266.

86 Campbell, »Liquor and Liberals«, p. 32.

87 Philip S. Gorski, »Bourdieusian Theory and Historical Analysis. Maps, Mechanisms, and Methods«, in: Philip S. Gorski (ed.), Bourdieu and Historical Analysis, Durham, London 2013, p. 327-366, at p. 357.

88 Yves Gingras, "L'institutionnalisation de la recherche en milieu universitaire et ses effets", in: Sociologie et sociétés 23/1 (1991), p. 41-54, at p. 41.

89 Christian Lamouroux, "Qualification des hommes et procedures administratives«, in: Actes de la recherche en sciences sociales 133 (2000), p. 26-31, at p. 26.

90 Bourdieu/Christin/Will, "Sur la science de l'État«, p. 5. Works in the field of organization theory have suggested that the concept of fields and its related notions can be used as a synonym for administrative organizations: e. g. Mustafa Emirbayer, Victoria Johnson, „Bourdieu and Organizational Analysis«, in: Theory and Society 37 (2008), p. 1-44; Diane Vaughan, „Bourdieu and Organization: The Empirical Challenge«, in: Theory and Society 37 (2008), p. 65-81). Because of the size of the literature generated by this suggested use of the theory of fields, and because of the omnipresence of organizations in public administration, it could be tempting to imitate this practice in studying administrative history. Yet it presents three dangers. The first resides in the epistemological risks associated with transposing an analytical concept to a different level of analysis, something Bourdieu himself was rather cautious about: Bourdieu/Wacquant, Réponses. The second danger is that the borders of a formal organization and a field do not usually match; this is particularly the case in public administration because of, e.g., geography, globalization, and the influence of international organizations: George Steinmetz, "État-mort, État-fort, État-empire», in: Actes de la recherche en sciences sociales 201-202 (2014), p. 112-119, at p. 118. Finally, using organizations defined by the state as units of analysis defeats the purpose of the theory and prevents the radical doubt that researchers need to have. In a similar way, other works have used only one concept or another of the theory of fields in their analysis of public administration; see Thomas J. Catlaw, Qian Hu, "Legitimacy and Public Administration. Constructing the American Bureaucratic Fields«, in: American Behavioral Scientist 53 (2009/10), p. 458-481; and Peggy McDonough, "Habitus and the Practice of Public Service», in: Work, Employment and Society 20 (2006), p. 629-647. However, because it is necessary to keep the concepts of capital, field, and habitus connected to take full advantage of the theory (see Emirbayer/Johnson, "Bourdieu and Organizational Analysis«), it appears unfruitful to adopt such an approach in future studies of the history of public administration. 


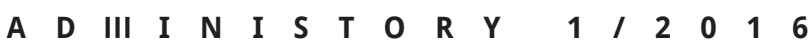

\section{Abstract}

This article explores how French sociologist Pierre Bourdieu's theory of fields, by encouraging a critical analysis of what the state does and produces, can bring a new perspective to studying the history of public administration. To do so, it explains how the theory can be used to perform historical analysis of public administration, and examine the case of the introduction of the merit system in the Canadian federal public administration to illustrate its perspective. The article concludes that the interplay among the theory's core concepts - capital, field, and habitus - offers a reconceptualization of the study of administrative history that integrates historical, social, and political elements.

\section{About the Author}

Caroline Dufour (MA Université Laval, PhD Université de Montréal) is Associate Professor at the School of Public Policy and Administration at York University, Toronto, Canada. Her research interests include administrative history and the visual approach to public administration. She teaches in the fields of public administration and policy analysis. 